\title{
The Influence of Government Transparency, Implementation of the Government Accounting Standards and Internal Control System on Quality of Financial Statement (A Survey Conducted in the Village Administration Bandung Regency, Indonesia)
}

\author{
Imam Surya Prayogo*, Erna Setiany \\ Department of Accounting Universitas Mercu Buana Indonesia
}

DOI: $\underline{10.36348 / \mathrm{sb} .2020 . v 06 \mathrm{i} 07.001}$

| Received: 18.02.2020 | Accepted: 25.02.2020 | Published: 30.07 .2020

*Corresponding author: Imam Surya Prayogo

Abstract

This research to examine The Influence of Government Transparency, Implementation of the government accounting standards and Internal Control System on Quality of financial statements. Population in this research is all villages in the government of Kabupaten Bandung government environment. The number of sample the respondent on this is as many as 73 of village staff and using a technique the withdrawal of sample by means of clusters of random sampling. Data were collected using a questionnaire which used interval scale. Distribution and collection of questionnaires was carried out in November 2019 and the number of questionnaires returned was 70 questionnaires or $96 \%$. The results of testing showed transparency the government did not influenced the quality of the financial statements in the village administration Bandung regency, while the implementation of the government accounting standards and internal control system influenced the quality of the financial statements in the village administration Bandung regency.

Keywords: Government Transparency, The Government Accounting Standards, Internal Control System, Quality of Financial Statement.

Copyright @ 2020: This is an open-access article distributed under the terms of the Creative Commons Attribution license which permits unrestricted use, distribution, and reproduction in any medium for non-commercial use (NonCommercial, or CC-BY-NC) provided the original author and source are credited.

\section{INTRODUCTION}

Minister of Home Affairs Regulation No. 13 of 2006 in Indonesia, the area financial reports are financial statements prepared to provide relevant information about the financial position and all transactions conducted by the local government during the reporting period.

One of the measures taken to achieve transparency and accountability of public finance management is the delivery of government financial accountability report that meets the principles on time and are prepared to follow the Government Accounting Standards. As a consequence, the government is required to prepare financial reports as a form of accountability for the implementation of the State Budget and / or the Regional Budget.

The results of the Supreme Audit Agency of Indonesia examination on 542 Regional Government Financial Statements in 2017 revealed a Fair Opinion without Exception opinion on 411 (76\%). Regional Government Financial Statements, Fair Opinion with Exception opinion on 113 (21\%). Regional Government Financial Statements, and TMP opinion on 18 (3\%) Regional Government Financial Statements. These conditions illustrate that the quality of Regional Government Financial Statements has not fully met the qualitative characteristics of adequate financial statements.

That some of the problems in relation to the financial management of the village over the years. First, regulatory limitations. That the government's good will and political will by presenting specific regulations on villages to date has not been enough to help the village head and his apparatus. This condition is clearly seen from the delays and difficulties of the village government in the preparation of village financial and activity planning. Almost all village legislation that mandates derivative regulations through local regulations has not yet been followed up. 
This condition is clearly seen from the delays and difficulties of the village government in the preparation of village financial and activity planning. Almost all village regulations that mandate derivative regulations through Regional Regulations and Regional Regulations have not been followed up on.

Besides accountability report that made the village has not followed the standards and prone to manipulation. And the Regional Government Budget compiled does not fully describe the needs of the village. The Corruption Eradication Commission, Johan Budi, found 14 potential problems in managing village funds totaling Rp 20.7 trillion in the 2015 Revised State Budget and Expenditure. It is planned that the funds will be channeled to 74,093 villages throughout Indonesia, the problem which began in January 2015 consists of aspects of institutional regulation, aspects of governance, aspects of supervision and aspects of human resources.

According to the Guidelines for Strengthening the Safeguarding of Regional Development Programs, the National Investment Board and the Minister of Home Affairs Regulation [1], transparency is a principle that guarantees access or freedom for everyone to obtain information about the administration of the government, namely information about the policy making process and its implementation and the results achieved.

In addition to accountability and transparency, government financial reports that are prepared and presented must be applied based on accounting principles in accordance with government accounting standards in Indonesia so that the quality of financial statements is improved.

To provide adequate confidence in the reliability of the presentation of government financial statements, a Government Internal Control System is required. The Committee of Sponsoring Organizations [2] implements an internal control framework in five components, namely 1) the environment or control environment, 2) risk assessment, 3) control activities, 4) information and 5) monitoring.

Research on the quality of financial statements has been widely carried out. The research shows different results. Among them is research conducted by Dwiyanti [3] the results of the study revealed that government accounting standards and internal control systems affect the quality of financial statements. So the higher the application of government accounting standards and internal control systems, the higher the quality of regional financial reports.

Ratnasari [4] the results of the study revealed that government accounting standards, internal control systems simultaneously have a positive and significant effect on the quality of government financial statements. Septo [5] the results of the study revealed that the application of government accounting standards affects the quality of financial statements, this is because if the government accounting standards are applied properly and correctly then it is certain that the resulting local government financial reports are getting better quality because they have been prepared in accordance with regulations exist.

Rachmawaty [6] the results of the study revealed the transparency of local government financial reports significantly influence the quality of local government financial reports. Septiningtyas [5] results of the study revealed that government accounting standards have a positive effect on the quality of government financial statements. While the transparency of financial statements and internal control systems does not affect the quality of local government financial reports.

With factors that affect the quality of financial reporting such as government transparency, implementation of government accounting standards and internal control systems, the financial statements that are accounted for will be in accordance with the principles of the government in Indonesia so that there is trust from the public towards the government in terms of managing state finances.

Based on the background described above, the author intends to conduct research under the title "the influence of government transparency, implementation of government accounting standards and internal control systems on the quality of financial statements".

\section{LITERATURE REVIEW}

\section{Agency Theory}

Agency theory describes the relationship between shareholders as principle and management as agents. Management is a contracted party by shareholders to work in the interests of shareholders. Because they are chosen, the management must account for all their work to shareholders [7].

The agency relationship is a contract in which one or more persons (the principal) govern another person (the agent) to perform a service on behalf of the principal and authorized agent make the best decisions for the principal. If both parties have the same goal to maximize the value of the company, then it is believed that the agent will act in a manner consistent with the principal's interests. According to agency theory, conflicts between principals and agents can be reduced by aligning interests between principals and agents. The presence of managerial ownership (insider ownership) can be used to reduce agency costs that may arise, as, which owns the company expected the manager to feel the direct benefits of each decision. 


\section{Quality of Financial Statements}

The Indonesian Institute of Accountants [8] suggests the meaning of Financial Statements is a structure that presents the financial position and financial performance in a general purpose entity of financial statements for public purposes is the presentation of information about the financial position, financial performance and cash flow of the entity which is very useful for make economic decisions for its users. Minister Regulation No. 13 of 2006, the area financial reports are financial statements prepared to provide relevant information about the financial position and all transactions conducted by the local government during the reporting period.

\section{Government Transparancy}

Transparency is built on the basis of a free flow of information. All government processes, institutions and information need to be accessible to interested parties and the available information must be sufficient to be understood and monitored. Mahsun [9] states that transparency is providing financial information that is open and honest to the community based on the consideration that the public has the right to openly and comprehensively acknowledge the responsibility of the government in managing the resources entrusted to him and his compliance with laws and regulations. Tahir [10] state that government transparency is providing clear information about procedures, costs and responsibilities, easy access to information, procedures used are good enough in the system coverage management information, administrative procedures, public communication by the government.

\section{Implementation of Government Accounting Standards}

Based on Government Regulation No. 71 of 2010 concerning Government Accounting Standards states that the Government Accounting System is a systematic series of procedures, organizers, equipment, and other elements to realize the accounting function from the analysis of transactions to financial reporting within the government organization. Suwanda [11] states that Government Accounting Standards are the accounting principles applied in preparing and presenting government financial reports. Furthermore according to Mahmudi [12] Government Accounting Standards contain accounting principles applied in preparing and presenting financial reports to government organizations. Siregar [13] that Government Accounting Standards are accounting principles applied in the preparation and presentation of government financial statements, so it can be concluded that government accounting standards are accounting principles used as guidelines in preparing and presenting government financial reports, both the central government or region.

\section{Internal Control System}

Government Regulation No.60 Year 2008, the understanding of the Internal Control System is an integral process in the actions and activities carried out continuously by the leadership and all employees to provide adequate confidence in the achievement of organizational goals through effective and efficient activities, reliability of financial reporting, security of State assets and observance of laws and regulations. Romney, Marhsall \& Steinbart [14] internal control (internal control) is a process that is implemented to provide guarantees that meet several objectives of internal control, including maintaining assets, maintaining records in sufficient detail for proper company asset reporting and accurate, provide accurate and reliable information, prepare financial statements with specified criteria, encourage and improve operational efficiency, encourage compliance in managerial matters, and meet the requirements of existing regulations and regulations.

Control Environment in the Government Decree 60 of 2008 Article 4 states that the head of Government Agencies are obliged to create and maintain a control environment that lead to positive behaviors and conducive to the implementation of the Internal Control System in the work environment.

\section{HYPOTHESIS}

\section{The Influence of Government Transparency on the Quality of Financial Statements}

Transparency is built on the basis of a free flow of information. All government processes, institutions and information need to be accessible to interested parties and the available information must be sufficient to be understood and monitored. According to the Guidelines for Strengthening the Safeguarding of Regional Development Programs, Bappenas and the Ministry of Home Affairs 2002, page 18 states that the definition of transparency is a principle that guarantees access or freedom for everyone to obtain information about governance, namely information about the policy of the process of making and implementing it and the results that are achieved.

$\mathbf{H}_{\mathbf{1}}$ : Perception of the Influence of Government Transparency has a positive effect on the Quality of Financial Statements.

\section{Implementation of Government Accounting Standards on the Quality of Financial Reporting Indonesian Regulation No. 71 of 2010 article 1 paragraph (3) concerning Government Accounting Standards, government accounting standards (SAP) are accounting principles applied in preparing and presenting government financial reports. Thus SAP is a requirement and basis that has legal force in an effort to improve the quality of government financial reporting in Indonesia.}


$\mathbf{H}_{2}$ : Perception of the Implementation of Government Accounting Standards has a positive effect on the Quality of Financial Statements.

\section{Internal Control Systems on the Quality of Financial Statements}

The internal control system includes the organizational structure, methods and measures that are coordinated to safeguard the organization's wealth, check the accuracy and reliability of accounting data, encourage efficiency and encourage compliance with management policies. Internal controls are needed to make it easier to find or analyze existing problems or issues that may arise in the process of achieving goals that the achievement of objectives can we know clearly.

$\mathrm{H}_{3}$ : The perception of the Internal Control System has a positive effect on the Quality of Financial Statements

\section{RESEARCH METHODS}

This research is a causal quantitative study because it aims to test hypotheses about influence. Causal research is research conducted to find the cause of one or more problems [15].

The population in this study were all villages within the Government of Bandung Regency Government. The number of samples in this study were 73 village officials. The sampling technique is Cluster Random Sampling. In this study, data collection was done by using a Interval scale questionnaire technique. And the method of analysis in this study is the Structural Equation Model (SEM) with the help of Partial Least Square Software (PLS), namely SmartPLS version 3.0.

\section{RESULTS}

Table-1: Results of the Description of the Influence of Government Transparency

\begin{tabular}{|c|l|c|}
\hline No. & \multicolumn{1}{|c|}{ Dimension } & Average \\
\hline 1 & $\begin{array}{l}\text { Public communication by the } \\
\text { government }\end{array}$ & 4,24 \\
\hline 2 & $\begin{array}{l}\text { People's right to access to } \\
\text { information }\end{array}$ & 4,19 \\
\hline 3 & Disclosure & 4,44 \\
\hline \multicolumn{2}{|c|}{ Average } & $\mathbf{4 , 2 3}$ \\
\hline
\end{tabular}

Based on the results of the table above it is known that the response of village officials to government transparency by an average of 4.23 , which means that village officials tend to answer agree to the variable influence of government transparency.
Table-2: Results Description of Implementation of Government Accounting Standards

\begin{tabular}{|c|l|c|}
\hline No & \multicolumn{1}{|c|}{ Dimension } & Average \\
\hline 1 & Accounting basis & 4,54 \\
\hline 2 & Historical value & 3,91 \\
\hline 3 & Realization & 3,80 \\
\hline 4 & $\begin{array}{l}\text { The substance outperforms } \\
\text { the formal form }\end{array}$ & 3,97 \\
\hline 5 & Periodicity & 4,01 \\
\hline 6 & Consistency & 4,04 \\
\hline 7 & Complete disclosure & 3,97 \\
\hline 8 & Presentation is reasonable & 4,27 \\
\hline 9 & Planning & 4,36 \\
\hline 10 & Implementation & 4,46 \\
\hline 11 & Supervision & 4,49 \\
\hline 12 & Accountability & 4,46 \\
\hline \multicolumn{2}{|c|}{ Average } & $\mathbf{4 , 1 9}$ \\
\hline \multicolumn{2}{|c|}{} \\
\hline
\end{tabular}

Based on the results of the table above it is known that the response of the village apparatus to the implementation of Government Accounting Standards with an average of 4.19 , which means that the village apparatus tends to answer amenable to the variable Implementation of Government Accounting Standards.

Table-3: Results Description of the Internal Control System

\begin{tabular}{|c|l|c|}
\hline No. & \multicolumn{1}{|c|}{ Dimension } & Average \\
\hline 1 & Control environment & 4,21 \\
\hline 2 & Risk assessment & 4,08 \\
\hline 3 & Control activities & 3,97 \\
\hline 4 & Information and communication & 3,97 \\
\hline 5 & Internal control monitoring & 4,12 \\
\hline \multicolumn{2}{|c|}{ Average } & $\mathbf{4 , 1 1}$ \\
\hline
\end{tabular}

Based on the results of the table above, it is known that the response of village officials to the Internal Control System with an average of 4.11, which means that village officials tend to answer agree to the variable Internal Control System.

Table-4: Results Description of the Quality of Financial Statements

\begin{tabular}{|c|l|c|}
\hline No. & \multicolumn{1}{|c|}{ Dimension } & Average \\
\hline 1 & Relevan & 4,03 \\
\hline 2 & Reliable & 4,17 \\
\hline 3 & Can be compared & 4,14 \\
\hline 4 & Can be understood & 4,07 \\
\hline \multicolumn{2}{|c|}{ Average } & $\mathbf{4 , 0 9}$ \\
\hline
\end{tabular}

Based on the results of the above table, it is known that the response of village officials to the Quality of Financial Statements with an average of 4.09 , which means that village officials tend to answer agree to the variable Quality of Financial Statements. 
Imam Surya Prayogo \& Erna Setiany., Sch Bull, July, 2020; 6(7): 174-181

Table-5: Dimension Constructive Validity Test Results Using AVE

\begin{tabular}{|l|c|c|c|}
\hline \multicolumn{1}{|c|}{$\begin{array}{c}\text { Indicators / } \\
\text { Dimensions }\end{array}$} & (AVE) & $\begin{array}{c}\text { Off } \\
\text { Off }\end{array}$ & Description \\
\hline Reliable & 0,734 & 0,500 & Valid \\
\hline Can be compared & 1,000 & 0,500 & Valid \\
\hline Can be understood & 1,000 & 0,500 & Valid \\
\hline $\begin{array}{l}\text { Community Right } \\
\text { To Access } \\
\text { Information }\end{array}$ & 0,699 & 0,500 & Valid \\
\hline $\begin{array}{l}\text { Information and } \\
\text { Communication }\end{array}$ & 0,816 & 0,500 & Valid \\
\hline Control Activities & 0,836 & 0,500 & Valid \\
\hline $\begin{array}{l}\text { Public } \\
\text { Communication by } \\
\text { the Government }\end{array}$ & 0,780 & 0,500 & Valid \\
\hline $\begin{array}{l}\text { Control } \\
\text { Environment }\end{array}$ & 0,629 & 0,500 & Valid \\
\hline Monitoring & 0,823 & 0,500 & Valid \\
\hline $\begin{array}{l}\text { Application of } \\
\text { Government } \\
\text { Accounting } \\
\text { Standards }\end{array}$ & 0,612 & 0,500 & Valid \\
\hline Disclosure & 0,963 & 0,500 & Valid \\
\hline Risk Assessment & 0,795 & 0,500 & Valid \\
\hline Relevant & 0,595 & 0,500 & Valid \\
\hline
\end{tabular}

Based on the table above it can be seen that all dimensions produce Average Variance Extracted (AVE) values greater than 0.5. Thus the indicator is declared valid to measure its dimensions.

Tabel-6: Construction Reliability Test Results

\begin{tabular}{|l|c|c|}
\hline \multicolumn{1}{|c|}{ Dimension/Variabel } & $\begin{array}{c}\text { Cronbach's } \\
\text { Alpha }\end{array}$ & $\begin{array}{c}\text { Composite } \\
\text { Reliability }\end{array}$ \\
\hline Reliable & 0,818 & 0,892 \\
\hline Can be compared & 1,000 & 1,000 \\
\hline Can be understood & 1,000 & 1,000 \\
\hline $\begin{array}{l}\text { Community Right To } \\
\text { Access Information }\end{array}$ & 0,891 & 0,920 \\
\hline $\begin{array}{l}\text { Information and } \\
\text { Communication }\end{array}$ & 0,775 & 0,899 \\
\hline Control Activities & 0,804 & 0,911 \\
\hline $\begin{array}{l}\text { Public Communication by } \\
\text { the Government }\end{array}$ & 0,859 & 0,914 \\
\hline $\begin{array}{l}\text { Quality of Financial } \\
\text { Statements }\end{array}$ & 0,885 & 0,907 \\
\hline Control Environment & 0,882 & 0,911 \\
\hline Monitoring & 0,785 & 0,903 \\
\hline $\begin{array}{l}\text { Application of Internal } \\
\text { Control Accounting } \\
\text { Systems }\end{array}$ & 0,930 & 0,939 \\
\hline $\begin{array}{l}\text { Application of } \\
\text { Government Accounting } \\
\text { Standards }\end{array}$ & 0,942 & 0,950 \\
\hline Disclosure & 0,962 & 0,981 \\
\hline Risk Assessment & 0,743 & 0,886 \\
\hline Relevant & 0,770 & 0,854 \\
\hline Government Transparency & 0,939 & 0,948 \\
\hline
\end{tabular}

Based on the table above it can be seen that the Chronbach alpha value is greater than 0.6 and the composite reliability value is greater than 0.7 . Thus, based on the calculation of the Chronbach alpha value and the composite reliability value of all indicators expressed reliable in measuring dimensions, and dimensions are also declared reliable in measuring the variables.

Table-7: R-Square result

\begin{tabular}{|c|c|}
\hline Dependent Variable & R Square Adjusted \\
\hline Quality of Financial Statements & 0,549 \\
\hline
\end{tabular}

Table 7 shows that the R-square value of the Financial Statement Quality variable is 0.549 or $54.9 \%$. This can indicate that the diversity of the variables of the Quality of Financial Statements can be explained by the variables of Government Transparency, Implementation of Government Accounting Standards, and the Internal Control System is $54.9 \%$. while the remaining $45.1 \%$ is contributed by other variables not discussed in this study.

Table-8: Hypothesis Testing Results

\begin{tabular}{|l|c|c|c|}
\hline \multicolumn{1}{|c|}{ Variabel } & $\begin{array}{c}\text { Original } \\
\text { Sample }\end{array}$ & $\begin{array}{c}\text { T } \\
\text { Statistics }\end{array}$ & $\begin{array}{c}\text { P } \\
\text { Values }\end{array}$ \\
\hline $\begin{array}{l}\text { Influences of } \\
\text { Government } \\
\text { Transparency -> } \\
\text { Quality of Financial } \\
\text { Statements }\end{array}$ & 0,148 & 1,037 & 0,300 \\
\hline $\begin{array}{l}\text { Implementation of } \\
\text { Government } \\
\text { Accounting Standards } \\
\text {-> Quality of Financial } \\
\text { Statements }\end{array}$ & 0,352 & 2,441 & 0,015 \\
\hline $\begin{array}{l}\text { Internal Control } \\
\text { System -> Quality of } \\
\text { Financial Statements }\end{array}$ & 0,452 & 4,384 & 0,001 \\
\hline
\end{tabular}

In the table above, the influences of government transparency on the quality of financial statements can be seen that the value of $\mathrm{T}$ statistics is 1.037 with a $p$-value of 0.300 . The test results show that the value of $\mathrm{T}$ statistics $<1.96$ and p-value $0.300>0.05$. This means that it can be concluded that there is no significant effect between the effect of government transparency on the quality of financial statements.

Implementation of government accounting standards on the quality of financial statements on the test results can be seen that the value of $\mathrm{T}$ statistics is 2.441 with a p-value of 0.015 . The test results show that the value of $\mathrm{T}$ statistics $>1.96$ and $\mathrm{p}$-value $0.015<0.05$. This means it can be concluded that there is a significant influence on the implementation of government accounting standards on the quality of financial statements. Thus it can be interpreted, the higher the application of standardization of the village government then tends to improve the quality of financial statements. 
Internal control system on the quality of financial statements, the test results can be seen that the value of $\mathrm{T}$ statistics is 4,384 with a $\mathrm{p}$-value of 0,000 . The test results show that the value of T statistics $>1.96$ and p-value $0,000<0.05$. This means that it can be concluded that there is a significant influence of the internal control system on the quality of financial statements. Thus it can be interpreted, if the higher the implementation of the internal control system, it tends to improve the quality of financial statements.

\section{DISCUSSION}

The test results show that there is no significant effect on Government Transparency on the quality of financial statements. And the direction of influence is positive, meaning that the more effective the application of Government Transparency in an agency, the better the quality of financial statements. This is inversely proportional to the theory, where transparency should be applied by government regulations so that there is trust from the community towards funds that have been allocated from the central government. So it can be said that government officials have not been fully open about the condition of financial statements to the public. One of the factors that caused the apparatus to not be open about the financial statements produced was that the community had not been given full access to provide opinions if an important meeting was held. The authorities provide access to the community if there are violations committed by criticizing and suggesting or it can also be through complaints to the local chairperson who will later be discussed by village officials regarding complaints from the community.

The results of the study revealed that the implementation of government accounting standards affects the quality of financial statements if the government accounting standards are applied properly and correctly then it is certain that the resulting local government financial reports are getting better quality because they have been prepared in accordance with existing regulations. One of the supporting factors is the existence of accountability in the presentation of financial statements and this can be seen from the history of education, work experience and accounting training organized by the local government of Bandung Regency.

The results revealed that the internal control system affected the quality of financial statements. The more optimal the implementation of the Internal Control System in a village government agency, the better the quality of financial statements. Some of the objectives of internal control, including maintaining assets, maintaining records in sufficient detail for reporting company assets that are accurate and accurate, providing accurate and reliable information, preparing financial reports with specified criteria, encouraging and improving operational efficiency, encouraging compliance in managerial terms, and meet the requirements of existing regulations and regulations.

\section{Picture}

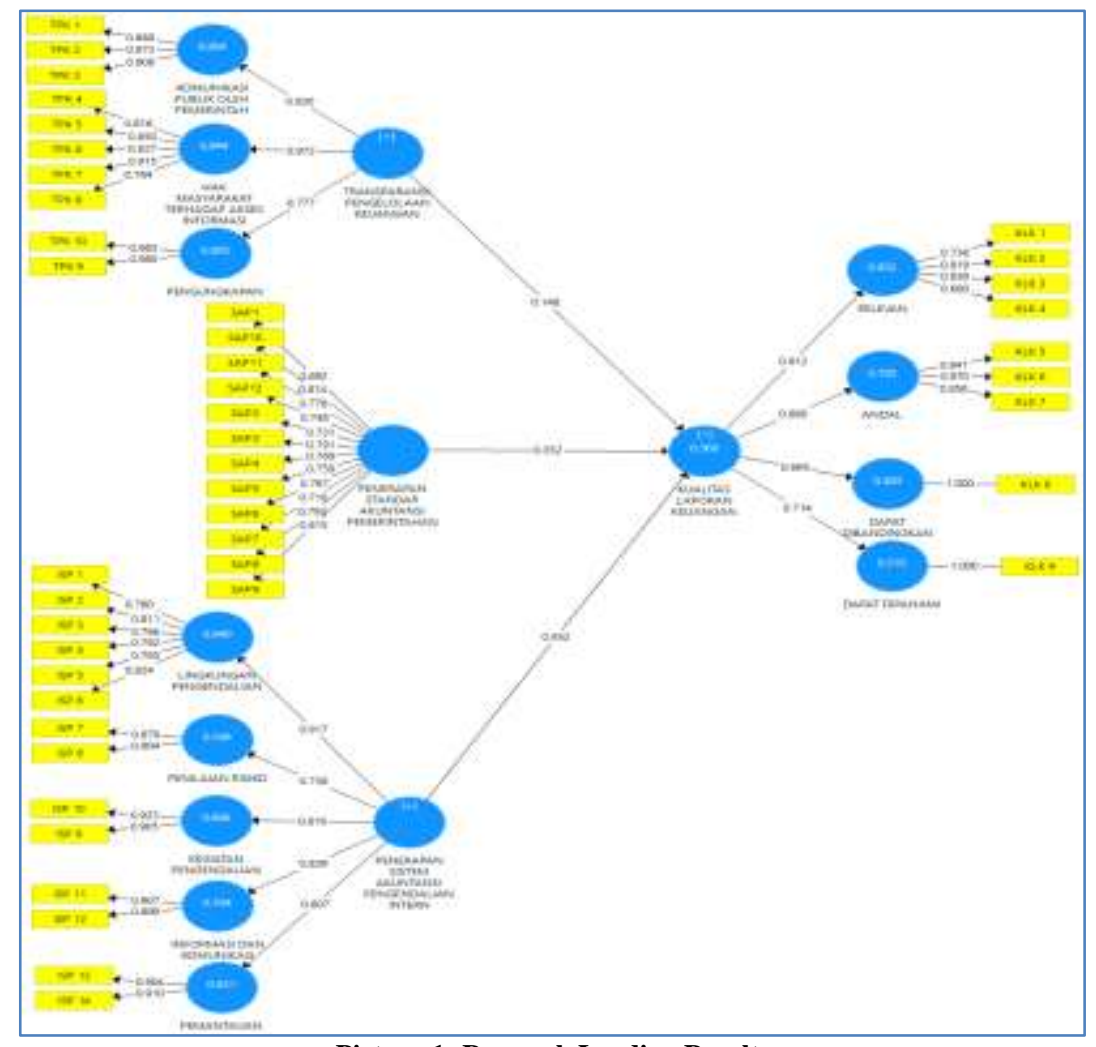

Picture-1: Research Loading Results 




Picture-2: Inner Model Results

\section{CONCLUSION}

Based on the formulation of the problem, hypothesis testing and discussion presented in the previous chapter it can be concluded as follows:

1) The perception of the application of government transparency does not affect the quality of financial statements in the Bandung regency village government, caused the transparency of financial statements in the Bandung area is only a medium for local governments to transparently inform local financial reports, while elements of public financial reports do not know the truth, so that the principle of transparency in the Bandung Regency is not in accordance with agency theory, where regional officials should inform the results of financial statements to the public or the surrounding community.

2) The perception of the implementation of village government accounting standards affects the quality of financial reports in
Bandung regency village government, caused the village government accounting standards are the quality standards of financial reports to keep the information presented reasonable and accountable so that its application must be carried out optimally.

3) The perception of the internal control system affects the quality of financial reports in the village government of Bandung Regency, this is because the internal control system can improve the quality of financial reports, the Internal Control System which is implemented thoroughly in actions and activities provides sufficient confidence to achieve the reliability of financial statements.

\section{RECOMMENDATION}

Based on the results of the discussion and conclusions above, the authors provide the following suggestions: 
1. Government of Bandung Regency Village, Bandung regency government must have a reliable internal control system in order to create the village of accountable financial management by conducting periodic evaluation of the implementation of the internal control system.

2. Next researcher, the next researcher is expected not to be fixed on the three variables in this study, namely the variable transparency of financial management, government accounting standards, internal control systems, but can add other factors that can improve the quality of village government financial reports.

\section{REFERENCES}

1. Minister of Home Affairs Regulation No. 13 of 2006 concerning Guidelines for Regional Financial Management

2. Setiyawati, H. (2013). The Effects of Internal Accountants 'Competence, Managers' Commitment to Organizations and the Implementation of the Internal Control System on the Quality of Financial Reporting. International Journal of Business and Management Invention, 2(11), 19 -27

3. Dwiyanti. (2017). The Effect of Determination of Government Accounting Standards and Internal Control Systems on the Quality of Regional Government Financial Statements. Thesis, Widyatama University.

4. Ratnasari. (2018). The Effect of Determination of Government Accounting Standards and Internal Control Systems on the Quality of Regional Financial Statements. Thesis, Pasundan University,
5. Republic of Indonesia Supreme Audit Board. Summary of Semester I 2018 Audit Results Republic of Indonesia. Accessed September 1, 2018 from the World Wide Web: http://bpk.go.id/assets/files/ihps/2018/I/ ihps_i_2018_1538459607.pdf

6. Rachmawaty. (2015). The Influence of Financial Report Transparency on the Quality of Financial Statements. Thesis, Widyatama University.

7. Jensen, M. C., \& Meckling, W. H. (1976). Theory of the firm: Managerial behavior, agency costs and ownership structure. Journal of financial economics, 3(4), 305-360.

8. Indonesian Institute of Accountants. (2015). Chartered Accountant Module: Internal Control and Information Systems. Indonesian Accountants Association Publisher.

9. Mahsun. (2015). Public sector accounting. Yogyakarta: BPFE

10. Tahir. (2011). Public Policy and Transparency in Regional Government Administration. Jakarta: Indonesian Library Press

11. Suwanda. (2015). Accrual Based Accounting Policy: Guided by SAP. Bandung: Rosda

12. Mahmudi. (2016). Public sector accounting. Yogyakarta: UII Press,

13. Siregar. (2017). Public Sector Accounting: Accrual-Based Regional Government Financial Accounting. Yogyakarta: YKPN College of Management.

14. Romney, M. B., Steinbart, P. J., \& Cushing, B. E. (2006). Accounting information systems (Vol. 2). Englewood Cliffs, NJ: Prentice Hall.

15. Sekaran. (2014). Research Methodology for Business (Research Methods for Business). Jakarta: Salemba Empat. 